\title{
Theorizing Citizenships in Late Modern ICT Societies
}

\author{
Jakob Svensson \\ jakob.svensson@kau.se, Karlstad University, Sweden
}

\begin{abstract}
In this paper I define citizenship, participation and the political for better understanding and analyses of political participations in late modern ICT societies. I approach the topic from a comprehensive understanding of developments both in society and technology, how they mutually reinforce each other and are best understood in tandem. Discussions of citizenship are concerned with normative macro-perspectives of the good society and how it should be organized often departing from micro-empirical studies of how society and political participation are changing. This combination of macroand micro-perspectives together with its multi- and interdisciplinary appeal makes citizenship ideal to approach from a transdisciplinary point of departure. In the paper I propose an understanding of citizenship as participation in political communities; ensembles of people addressing the organization of society and making sense of this address in a similar way. Citizenships are enacted in relation to the authority of a political community, an authority that streams out of the values and norms that are constructed and renegotiated through the participation of its members. Hence, it is both through participation that citizens and political communities are made. The paper ends with a proposal of how to categorize online participation and citizenship(s) in late modern ICT societies.
\end{abstract}

Keywords: Transdisciplinarity, late modernity, citizenship, participation, the political, governance, network society, convergence

Acknowledgement: This article has been made possible with support by the Wahlgrenska foundation, HumanlT and Karlstad University.

When digital information technologies become increasingly important for communicating in Western and connected communities, society as well as the individual takes on new and different meanings. Some scholars connect transformations of communication patterns to us entering into a new kind of society, network society (Benkler, 2006; Shirky, 2009), which according to Castells (2001) is governed by another form of sociability, networked individualism. With the possibility to communicate many to many in digital networks, together with enhanced processes of individualization in late modernity, it is argued that we are leaving mass society behind.

One subject area that has been discussed as particularly affected by these developments is citizenship. The rise of digital communication and the Internet have provided rays of hope for political engagement with new and different understandings of citizenship participation in an otherwise dark time of representative democracy marked by civic withdrawal from parliamentary politics. In connected societies the Internet is considered the new arena for political action, often lowering the political threshold with new and different forms for engaging people in deliberations about the structure and organization of society. When more and more people socialize, organize, contribute, inform and publish their concerns and themselves on the Internet, political participation take on different meanings and citizenships are enacted differently and hence needs to be theorized differently.

The purpose of this paper is to contribute to the theoretical discussions of citizenship for better understandings and analyses of political participations in late modern ICT societies. To achieve this it is important to avoid deterministic causal approached of relationships between technology, society and the individual and rather adopt a transdisciplinary understanding of contemporary developments and how they mutually reinforce each other. 


\section{Citizenship from a Transdisciplinary Perspective}

Discussions of citizenship are per se concerned with macro-perspectives, combining behavioral understandings of inhabitants engagement with socio-political theories of how society and politics are changing, connecting empirical studies of participation to normative visions of the good society and how it should be structured (see Isin \& Turner, 2002; Kivisto \& Faist, 2007). Citizenship has thus been studied from different disciplines and is in this sense multidisciplinary (see Nicolescu, 2002 , p. 42). Due to this multidisciplinarity, citizenship is also interdisciplinary, making use of a variety of methods from many disciplines (ibid., p. 43) as varied as quantitative content analyses in news studies (McNair, 2000), to more participatory observations in ethnographic studies of citizenship (see Camauë r, 2000). What is interesting with the idea of transdisciplinarity is its concern of what is between and across disciplines (Nicolescu, 2002, p. 44). Transdisciplinarity thus becomes a new form of learning and problem solving involving cooperation among different parts of society and academia (Thompson Klein et al. 2001, p. 7). One of the tasks of transdisciplinarity is to clarify theoretical concepts and their value (ibid., p. 5). My aim, to define citizenship to better understand political participation in late modern ICT societies, is in this sense transdisciplinary. Citizenship in itself could be understood as transdisciplinary since the concept implies the individual and society at the same time. Discussing citizenship we need to attend to individual behavior and motivations as well as normative theories of societal organization and empirical studies of cultural, technological and societal changes. Hence, citizenship makes a perfect subject area to study from a transdisciplinary perspective.

One aim of transdisciplinarity is to understand the present world (Nicolescu, 2002, p. 46) beyond the contemporary proliferation of disciplines (ibid., p. 33; see also Thompson Klein et al. 2001, p. 4). In Nicolescu's (2001) grand manifesto of transdisciplinarity he uses arguments from Quantum Physics to abstract art. Even though my knowledge only spans over selected fields in the Social and Political Sciences, I believe the transdisciplinary quest for understanding beyond strict academic disciplines is beneficial when analyzing citizenship due to changes in both technology and culture. As I will argue in this paper, changes in technology and culture are best understood in tandem, and the purpose of this paper is to understand political participations in ICT societies regardless if approaching this area from Information Systems, Media and Communication Studies, Sociology, Political Science or Philosophy. Research within disciplines can be clarified by transdisciplinary approaches and vice versa, transdisciplinarity is nourished by disciplinary research (Nicolescu, 2002, p. 45). Hence disciplinary and transdisciplinary research are complementary (see also Thompson Klein et al. 2001, p.4).

In this paper I will consider both socio-technological and political scientific understandings and the dialectics between them. Before turning to technological aspects of contemporary political participation, I will start discussing citizenship from a socio-cultural understanding of our time as late modern.

\section{Changing Participatory Patterns in Late Modernity}

The victory of liberal democracy and market capitalism, symbolized with the Berlin Wall coming down 1989 as the last reminiscent of communist society, led Fukuyama (1992) to proclaim the end of history. Ten years later some theoreticians (Carter \& Stokes, 1998; Bauman, 2001) observed the side effects of liberal democracy; social disintegration and voter alienation. Citizens in western liberal societies more frequently declare themselves to be dissatisfied (Bentivegna, 2006). Market capitalism as way to organize public administration under the promise of New Public Management, seems to have reduced citizenship to consumption, and turned citizens away from traditional arenas of political participation (Bauman, 2001). Boggs (2000) refers to this as the great retreat.

The practices of citizenship are changing. Some claim that inhabitants are withdrawing away from a supposedly vivid agora full of debating citizens, and becoming increasingly sceptical and distrusting, with the result of a decrease in political participation (Fishkin, 1991). Such a dystopian description is mostly echoed in parliamentary frameworks. For example, the EU-elections June 
2009 were claimed to be the biggest transnational elections in history. However, only $43 \%$ of the electorate chose to cast their vote, making participation the lowest in the 30 years of EU election history. Low participation in elections together with a decreasing faith in politicians and membership in political parties (Peterson, Westholm, \& Blomberg, 1989; Olsson, 2006) have launched a debate on civic disinterest, distrust and the legitimacy of parliamentary politics and its representatives.

Despite decreasing participation in parliamentary arenas, there are other sites of political debate, not solely limiting political participation to representative democracy, suggesting new arenas for citizenship practices. It is in this context the Internet enters into the discussion forwarding a picture of engaged and interactive citizens under the promise of web 2.0 and emerging social media platforms.

Sociologists explain changing participatory patterns in part as a result of us entering a new phase of history: late modernity (Giddens, 1991; Beck, 1995; Bauman, 2001). Dahlgren (2006) characterizes late modernity by identifying two interrelated cultural processes at work: dispersion of unifying cultural frameworks and individualization. The first refers to the increasing pluralisation, fragmentation and nichification of society along lines of ethnicity, media consumption, cultural interests, life styles, interests, tastes etc (ibid.). Individualization refers to a lacking sense of social belonging and a growing feeling of personal autonomy (ibid.). Disinterest towards political participation on the parliamentary arena and withdrawal from representative democracy can be understood in the light of these cultural changes.

Bauman (2001), who put forward a dystopic vision of individualism in late modernity, equates the civic withdrawal away from formal politics, with a larger withdrawal away from also collective identities and community sensibilities (se also Boggs, 2000). However, a more positive account of late modern political participation is provided by Beck $(1995,1998)$ and his concept of sub-politics. He regards individualization and dispersion of unified cultural frameworks as not necessarily inhibiting political participation and citizenship. Supporting this more positive account is the rise of new arenas for political participation, such as everyday life at the home, the street or online, arenas with activities such as signing petitions, voicing concerns and protests by creating and joining new groups and associations outside the Parliament (Peterson, Westholm, \& Blomberg, 1989; Beck, 1995; Bennett \& Entman, 2001; Dahlgren, 2001). Even though these groups seem to be more short-lived, single-issue oriented and digitally managed, they point out late modern processes of individualization as not resulting in a general withdrawal from politics, but rather a more lifestylebased approach to participation (Giddens, 1991). It seems that political participation online increasingly has become part of an individual self-realization project. This also underlines reflexivity as a dominant theme in late modernity. Reflexivity implies that we consider ourselves and our practices from different perspectives, always re-considering previously acquired knowledge (Giddens, 1991).

Before assessing the specifics of citizenship practices and political participation, I will attend to the more technologically ascribed characteristics of contemporary late modern societies.

\section{Convergence and Network Society}

Almost everyone agrees that the rise of digital communication and the Internet has resulted in remarkable changes in communication patterns and social organization at large. For example it can be argued that the advent of the printing press is tied to the rise of mass society and mass culture. Horkheimer (1947) and the Frankfurt School were early to discuss cultural forms as part of larger societal structure. Today, many scholars make a similar argument, connecting digital transformations of communication to changes in Western and connected societies (see Benkler, 2006; Shirky, 2009). With the possibility to communicate many to many in digital networks, it can be argued that we are leaving mass society behind. It is with the advent of cyberspace and virtual reality, that Nicolescu (2001, p. 75) identifies a need for transdisciplinary approaches to science.

Here it is important to avoid causal explanations of technology and society and to be critical of cyber-optimistic accounts. Andrejevic (2009) for example points out that only because media has transformed, political power has not, suggesting the possibility that political communities may adjust to incorporate digital media in ways that preserve existing power relations and dominant eco- 
nomic systems. But the implementation of digital technology has increased the possibility for anyone with Internet connection to construct, join and participate in online political communities (Benkler, 2006; Lü ders, 2007; Shirky, 2009). This is different from mass society. But what this will lead up to in terms of changing relations of power, and how and for whom these possibilities will be used, remains to be further researched.

One aspect of our changing society is illuminated by the concept of convergence. Convergence became a buzzword in the 1990's together with interactivity and the information society (Storsul \& Stuedahl, 2007). Literary, convergence means movement directed to the same point (Fagerfjord \& Storsul, 2007, p. 19). The starting point for assuming media convergence was the digitalization of signals (ibid., p. 20). In short convergence implies that in new digital environments, consumption and production of mediated messages are more intertwined and personalized than before.

Jenkins (2006) describes convergence as a flow of content across multiple media platforms, cooperation between multiple media industries, but convergence also entails a migratory behaviour of media audiences. In his book Convergence Culture (2006) he discusses the relationships between media convergence, collective intelligence and participatory culture. He claims that convergence encourages participation, complicating relations between top-down corporate media and bottom-up participatory culture (ibid.). It used to be difficult and expensive to mediate images, words and sounds from a media producer to a consumer. This favoured a complex media industry developing its own cultures and professions, underlining the division between production and consumption of information. With digital technology it has become easier to communicate within larger self-made networks. This collapse of "communication costs" (Benkler, 2006, p. 212), increasingly blurs the division between media production, media distribution and media consumption that tend to converge into one. People both like to consume, produce and share media. Now having the technological tools that support all these activities, we increasingly do so in one activity. Blogging about a news report is an example of this. Thus, the act of media consumption is increasingly interconnected with media production and media sharing, making the isolated act of media consumption rather a temporary behaviour than a permanent identity (Shirky, 2009).

The new digital communication infrastructure challenges traditional media institutions when control over media and information is less in the hands of the media professional (Shirky, 2009). As an example, mass media's gate-keeping function and monopoly on news framing is challenged through blogs and social media where communication is fast, far-reaching and networked. However convergence is an ambiguous concept since it is used differently both with regard to what is converging and what happens when something converges (Storsul \& Stuedahl, 2007). Fagerfjord \& Storsul $(2007$, p. 29$)$ is calling for a more complex framework for participatory culture than convergence invites.

From a transdisciplinary perspective, the socio-cultural changes, outlined in late modern perspectives, are happening at the same time as we experience this technological shift towards digitalization and convergence. This is not a coincidence but rather developments that go hand in hand. Digital technology and processes of late modernity mutually reinforce/ are part of the same trends towards a kind of networked individualism (Castells, 2001). Increasing individualization and the rise of the network as a dominant model of sociability, challenges our understandings of political participation and citizenship practices. Approaching this from a transdisciplinary framework, it is important not take on a determinist standpoint of either technology or society (Ekelin, 2007, p. 12; Frau-Meigs, 2007; Andrejevic, 2009; Roberts, 2009). Instead more efforts should be put into exploring the mutual co-construction of society, citizens and technology. Aspects of citizenship change when social conditions change (Dobson, 2003, p. 35); hence technology, society and citizenship develop in a dialectical relationship. The citizen is constituted as a subject of a social practice and at the same time also constitutes him/ herself as a subject of a certain social (and technological) practice. Citizens are both objects of domination as well as subjects with an ambition to create their own field of agency (Ekelin, 2007, p. 66). It is in these dialectical practices that we should start to theorize citizenship in late modernity for a more transdisciplinary understanding of contemporary ICT societies. 


\section{Citizenship, Participation and the Political}

Citizenship is often linked to privileges of membership of a political community (most often a nation state), privileges that consist of equal participation with fellow citizens on the making of the collective decisions that regulate social life of that political community (Barbalet, 1988, p. 2-4; Castles \& Davidson, 2000, pp. 32-33; Hoffman, 2004, p. 98; Bellamy, 2008, p. 1). Hence, citizenship is usually to describe a set of institutions, practises and identities connected to people's aspirations for democracy and equality (Bosniak, 2006, p. 11). Discussions of citizenship often revolve around its substance, its location and its subjects (ibid., p. 17). Thus larger concepts of citizenships have come to encompass a variety of elements in Social and Political Sciences, from the legal and sociological to the psychological and behavioural. Today there is a huge interest in citizenship, an interest which manifests itself not least through the many new types of citizenships continuously proliferating (see Dobson, 2003, p. 4, Hoffman, 2004, p. 1; Kivisto \& Faist, 2007, p. 2). The widespread use of the notion creates confusion what it actually entails and how it could be used across disciplines (Bosniak, 2006, p. 4). Looking through the literature it is obvious that ideas of citizenship have not been static, understandings have changed, been reshaped and hence also extended meanings of the concept to new disciplines and domains (Schuck, 2002, p. 131; Bosniak, 2006, p. 121). The question then arises; how is citizenship to be understood to be relevant and usable in late modern ICT societies, marked by digitalization, pluralisation and individualization?

Discussing citizenship here I will mostly attend to its substance and location; what citizenship is and where it takes place, addressing sociological and behavioural aspects of citizenship. This has of course implications for its subjects, who will get included or excluded and power relations (see Isin \& Wood, 1999; Bosniak, 2006), but is not the main focus here. Questions of the changing substance and location of citizenship in late modern ICT societies will inevitably get entangled into a discussion of our conceptions of the political and participation. Understanding citizenship(s) then is impossible without also attending to ideas of participation and the political and their interconnections. I start with citizenship.

\subsection{Citizenship}

In increasingly globalised, digital and non-territorial communities, the question has been posed whether if it is outdated and problematic to conceive of citizenship as membership in a nation state. However, globalization does not imply equal relations of interdependence since it is an asymmetrical process where some (in the south) are more dependent than others (in the north) (Dobson, 2003, pp. 12-13). For both these reasons the idea has been put forward that citizenship privileges should be expanded to all human beings, equating the category of citizen to humans in general (Turner, 1994; Linklater, 2002; Lister, 2002; Smith, 2002, pp. 105-106; Hoffman, 2004; Bellamy, 2008, p. 77). It is evident that the normative weight of universality attached to citizenship has made the concept a useful tool for political struggle, to fight injustice and to claim recognition for different and marginalized groups in society (see Cruikshank, 1999, p. 1; Lister, 2002; Bosniak, 2006, p. $35)$. This underlines an ambiguity within the concept; citizenship is associated with community belonging at the same time as it should apply to all human beings (Bosniak, 2006, p. 18). My argument is that in order to keep its relevance as an analytical tool for transdisciplinary knowledge, it is vital to make a distinction between human beings and citizens (Svensson, 2008, p. 24). In a similar argument Dobson (2003, p. 27) and Bellamy (2008, p. 79) underline citizenship as a specific kind of relationship that should not be broadened to encompass human relations generally. According to Aristotle (discussed in Dobson, 2003, p. 66), citizenship is always related to a constitution rather than humanity.

From a similar perspective, I believe that recognizing some centre of power, and authority, is important in order for the possibility to direct right claims as a citizen as well as to accept duties and regulations put on you as a citizen. In this sense, the practice of citizenship also entails accepting decisions made by others, or some sort of authority (polis), as implied by Aristotle's definition of citizens as ruling and being ruled in turn (discussed in Bellamy 2008, pp. 32-35). Also civic republi- 
cans recognize political authority as important for attaching civic virtues to (Dobson, 2003, p. 61). Therefore I have argued that citizenship is best understood as participation in a relation to some kind of authority (Svensson, 2008, p. 23). Participation in a political community also constructs the political authority in relation to which inhabitants become citizen.

Discussing citizenship as a form of membership practice, it is important to keep in mind that in contemporary globalised ICT societies, political community does not have to come in the shape of a nation state. The notion of political community does not imply per se that the community has to be bounded to territoriality (Dobson 2003, p. 72) or predetermined. Defining community around boundaries of interest and meaning-making instead makes more sense in a reflexive and late modern society with digital communication that in many cases transcends state territory and unites users around cultural interests, life styles and tastes. In a similar fashion Bruns (2009, p. 11) discusses online communities as groups of people with a set of shared values, beliefs, norms and ideas. These shared values, norms and ideas then constitute the core of the political community, out of which authority is constituted and claimed. Adherence to, and socialisation into, community values then becomes important for determining relations and power mechanisms within a community (Bruns, 2009, p. 5). For example, joining an online petition against the destruction of nearby bath- house, I soon realized that online visibility through activities such as facebooking and twittering would get me closer to the core of the activist group. By echoing popular argument through \#twittering and through posting encouraging entries on the Facebook fan page, I was not only showing my sympathy for the participatory and expressive values of the activist group, but I also reinforced these values and the authority of certain other active group members by commenting and re-tweeting their tweets.

However community norms and values are not fixed but subject to constant renegotiation and gradual change (Bruns, 2009, p. 11). Hence, communities in late modern ICT societies are porous, casual and debated constellations (Delanty 2002, pp. 171-172) and thus far from predetermined. A citizen's relation to the political community cannot be fixed and needs constant renegotiation. In late modernity we should also consider a network of more discursive political communities that citizens are potential members in (Dobson, 2003, p. 74). Meaning-making as the defining character of political community enables us to theorize about citizenship in a late modern ICT society across disciplines, making citizenship relevant even in a society characterised by reflexivity, physical and communication mobility and reach. An analysis of citizenship from this perspective implies that what we should look for, in order to understand citizenship, are processes of value negotiation and other meaning-making conditions that give ground for community authority in relation to which citizenships are enacted. As I mentioned in the previous section, the loci for such meaning making processes are changing in late modern ICT societies.

\subsection{Participation}

Analyses of citizenships will almost always enter into a discussion of rights and duties (Pocock, 1995). The rights that define citizenship are undergoing continual process of redefinition, not least through the political participation of citizens themselves. Given the fluidity of (political) communities in digital late modernity, civic rights and duties cannot be conceived of as fixed or stable entities. Accepting such structuring and dialectic relationship between community, participation and civic rights, participation becomes entangled into the very core of the concept of citizenship. In this sense citizenship as membership with rights and benefits attached to it, cannot be sustained without members participating for the forth living of the community. Citizenship thus implies the capacity to participate and the duty to use this capacity on which our other rights and democracy depend (Bellamy, 2008, pp. 13, 17, 25). Participation thus becomes so fundamental to citizenship that it is discussed both as a right and a duty.

Bellamy $(2008$, p. 3) claims that the mere possibility for equal participation affects how citizens regard their other duties such as abiding laws, paying taxes et cetera. From this perspective justice and equality becomes important as the social bonds that ties community members together as citizens. Dobson (2003) forwards justice rather than charity as defining the civic bond, and by doing 
this, distinguishes political from human community and citizenship from humanity. The promise of just and equal participation motivates us to collaborate with our fellow citizens. Nicolescu (2001, p. 89) discusses transdisciplinarity as the science discovering powerful social ties for finding our place in this world. A civic bond consisting of a promise of justice and equality could very well be such a social tie between people.

Discussing participation from a perspective of justice and equality we need to attend to issues of power and its relation to participation. Cruikshank (1999, p. 2) argues that modes of constituting and regulating citizenship, transform individual subjects into citizens. The will to empower through regimes of participatory democracy is both enabled and constrained by relations of power. The discussion board on a municipal webpage for example, is enabled by democratically elected representatives and their wish to be in dialogue with the citizenry. However, since these representatives also hold the decision-making power, what comes out of these deliberations is in their hands. Cruikshank (1999, p. 34) points out that contemporary non-participation and political disinterest places a strain upon liberal democratic government. The municipal discussion board may very well be a way for politicians to increase participation with the only purpose of solidifying the platform political representatives legitimates their exercise of power from. In Cruickshank's (1999, p. 3) analysis, the quest for empowering the poor and self-governing programmes for disenfranchised, are embedded in a liberal discourse of governance with all its asymmetrical power relations attached to it. In this way she argues that citizens are not born, but made through democratic modes of governance. Governance is defined here as relations of power that aim to guide and shape the actions of others (citizens), rather than force control and domination (ibid., p. 4), and hence a more subtle and sophisticated way of exercising power. ICT can very well be used for these purposes as municipal discussion boards online are examples of. Cruikshank thus underlines that democratic relations, also in a late modern, many-to-may and digitalized society, still constitute relations of power. Power should thus be constitutive to every analysis of citizenship and not just an add-on (see also Dobson, 2003, pp. 21, 62). Citizens are envisioned by political stakeholders that set up technologies for citizens' participation departing from their idealised visions of them. Inhabitants are therefore subject to power even as they participate as citizens in their own right (Cruikshank, 1999, pp. 20, 24).

Cruikshank $(1999$, pp. 32,45$)$ claims that power can both be voluntary and coercive at the same time, and she discusses political power as an ongoing result of forming and reforming authority. As discussed previously when defining community, authority is claimed through shared values and norms that constitute the core of the political community. It is then in the claiming of community authority, through negotiation of its values and norms, that power manifests itself.

From these discussions on participation, power and community, it becomes evident that citizenship is best understood as an activity, the act of doing something, rather than a fixed status, membership merely ascribing certain people as citizens and non-citizens (see also Svensson 2008, p. 23). From a discursive framework, citizenship is also best analyzed as a process, conflating political participation with citizenship so it becomes almost the same thing. Also community and participation becomes hard to separate from this perspective. Turner (1994, p. 159) for example uses a definition of citizenship as an ensemble of meaning making practices that constitutes individuals as members in a community. The character of political community is influenced by peoples' participation, which in turn is influenced by the political authority in relation to which citizens participate.

To sum up the discussion of citizenship then, it is claimed to consist of three components; membership, participation, rights and duties, components that stand and fall together (Bellamy, 2008, pp. 16, 25), but where participation become so entangled into the other two components that you may equate citizenship with participation. Citizenship (participation) is tied to a political community. Rights (to participate) and duties (to participate) are attached to this community. Citizenship as participation also fits very well a transdisciplinary perspective since cooperation among different parts of society is difficult without participation (see Thompson Klein, 2001, pp. 7, 195). 


\subsection{The political}

The previous definition of citizenship makes the notion of the political relevant to the theoretical framework. Some argue that citizenship could refer to any group, not only political ones or the nation state (see Smith, 2002; Bosniak, 2006). But the spheres where citizenships will be enacted are commonly understood as political (Bosniak, 2006, p. 20), or they become political when certain actions and identities are performed there (which is increasingly the case in late modernity which ideas of sub-, and life-politics underline (see Giddens, 1991; Beck, 1995)). The crucial question then is what the political consists of? What differentiates political communities from ordinary communities? What types of actions and identities differentiate a community so it can be considered political? What differentiates political participation from ordinary participation? Does the political merely connote a collective dimension and a dimension of shared common purposes (as the republicans would have it, see Dobson, 2003, p. 59)? Is then political participation the same as members' practices that are directed towards collective goals for the common good of the membership collective? A too narrow definition of the political may be limiting our perspectives, but on the other hand a too broad definition makes it useless as an analytical tool for understanding contemporary citizenship(s) across disciplines.

The political has a normative dimension because it deals with how society should be structured (Nord, 2008, p. 36). But our visions of good society are constantly changing, this pointing towards a definition of the political as a social and discursive construction, continuously being defined by citizens' practices (see Cruikshank, 1999, p. 17; Dahlgren 2001, pp. 40, 42). The practices of politics, understood here as the address of issues concerning the organization of society, are most often based in a principle of equality, an equal division of society's common goods (Rancière, discussed by Arsenjuk, 2005, pp. 88, pp. 91-92). Also according to Dobson (2003, p. 29) the principle of equal share entails a political type of obligation, opening up for a conception of citizenship beyond the state and beyond some kind of universal humanity. Different groups/ communities may have divergent opinions on the equal division of society's common goods and thus enter into debate with each other. Justice and equality seem to be entangled deep into the concept of the political.

The organization of society many times concerns the everyday life. Thus the political is also reconstituted at a micro-level (Cruikshank, 1999, p. 5). There citizenships are negotiated in the therapeutic, disciplinary, programmatic, institutional and associational activities of everyday life (ibid., p. 28), hence the private sphere constitutes a site of power relations and political struggle (Dobson, 2003, pp. 53, 56) where ideas of the structure and organization of society are expressed and put into practice. Identity politics, such as the feminist and gay movements, are examples of this. In this way the dichotomy private versus public becomes inadequate for defining the political. In a similar manner Nicolescu (2001, p. 22) forwards a multilevel understanding of reality that only a transdisciplinary perspective can grasp. He claims that interior and exterior faces are two facets of the same world (ibid. 89). Similarly Beck (1995, p. 143) underlines that the individual, not only social and collective agents, also shapes politics. For example, choosing to stay home with the kids is in this sense a political decision.

Citizenship transcends a divide between the public and private. Citizenship rights for example are attached to individuals, but the argument for having those rights has an important collective dimension (Bellamy, 2008, pp. 14-15). They appeal to certain goods for human beings leading a life together with others, they appeal to how society should be structured in an equal and just manner. It is a political community of members who can grant rights, in which members (citizens) seek fair terms of association to secure those goods necessary for them to pursue their doings on just and equal terms with fellow members (Pocock, 1995, p. 33; Bellamy, 2008, p. 16). Society and the individual are thus not in a dichotomised relation to each other, both are central for the political. Governance for example is a way of framing agency from an individual as well as a collective perspective (Cruikshank, 1999, p. 9). Hence it makes no sense to speak of the political, the social, the technological, the private or the public as separate domains. In this manner changes in both the social and the technological open up for new possibilities for political agency. 
Combining the discussion of the political with a definition of community based in an idea of similar practices of meaning-making, we end up with an understanding of political community as an ensemble of people addressing the organization of society and making sense of this address in a similar way, at the same time constructing and renegotiating values and norms out of which the authority of the community streams, in relation to which citizens are made. When people then participate and act upon shared meanings, address issues of the structure of society in relation to an authority, they enter into the practice of citizenship. In this way we can distinguish between political participation from other kinds of activities.

Political participation does not have to be purposeful engagement (as civic republicans would argue, see Bosniak, 2006, p. 92). In digital late modernity the political may occur outside of the Parliament and all over the socio-cultural landscape. Citizenship practices do not have to originate from within a self-proclaimed political community such as for example on hockey fan-pages where immigration is discussed as valuable for recruiting skilful players (Svensson, 2010). Digital technology and its uses for political, democratic and participatory practices, influence behaviours of both citizens and elected representatives, setting up new norms of what may be considered and valued as appropriate topics and practices in these communities. These digital changes of location and thus also norms and values of political communities in late modernity inevitably impact the substance of citizenship and our conceptions of the political. The political thus becomes entangled with citizenship and participation, implying that an attempt to understand participation and citizenship in an increasingly digital society, at the same time is an inquiry into the changing construction of the political. In other words, when citizenship practices are changing together with its arenas and emerging new communities, the conceptions of the political are also changing. For example blogging about your life as a home wife could be considered political.

Why spending so much time trying to sort out definitions of citizenship, participation and the political? In the debate on the Internet and its democratic and citizenship potential, cyber-optimists tend to equate every link, every social forum as a sign of political participation, whereas others dismiss online political participation as narcissistic self-promotion. Interactivity is not automatically political it has to be made political (Andrejevic, 2009), hence it is important to know what we are talking about when we delineate practices as political or not. A definition of citizenship as practices in relation to some kind of political community with authority attached to it (in the form of constructing and negotiating community values and norms) is important in order to distinguish political participation online from other kinds of online activities.

As I will attend to next, the discussion of changing loci of discussions of how to structure society (the political) implies that citizenship practices do not have to take place from within self- proclaimed political communities. I will end this paper with a suggestion of how to categorize participation and citizenship online.

\section{Categorizing the Field of Political Participation and Citizenships in Late Modern ICT Societies}

One framework for categorizing citizenship practices and political participation is to make distinctions between online political communities based on initiative and locality. First of all we have what I chose to label parliamentary communities, a top-down initiative localizing political participation within a representative democratic community. Within parliamentary communities the Internet (edemocracy, e-governance, e-administration) is used to promote and revitalize representative democracy. This has been labelled e-democracy from above (Coleman \& Blumler, 2009) since it is done from a top-down perspective with politicians or governmental officials launching different initiatives to engage and interest the citizenry in its doings. The municipal forums online for discussions with politicians are examples of parliamentary online communities.

The political system also includes civic organizations outside the Parliament, such as NGO's (non-governmental organizations) as well as individual citizens in loosely organized gatherings and groupings. These more bottom-up activist communities are different from parliamentary communities, where citizens themselves (or together) engage in, or initiate, political activities and collective 
action through and with the help of digital tools. The activist group protesting against the destruction of the neighbourhood bathhouse is an example of an activist community. Coleman \& Blumler (2009) label this as e-democracy from below

Having outlined a constructivist understanding of the political and citizenship practices in late modernity, it is also important to include more popular or cultural communities where the political (and hence also citizenship) may pop up everywhere in the popular and cultural sphere, not primarily set up for political or citizenship purposes. The Internet is the life- and sub-political medium par excellence, heightening cultural processes such as pluralisation, fragmentation, nichification and individualization. Hockey fan pages online are examples of cultural communities (Svensson, 2010).

A distinction of online participation and citizenship practices between parliamentary, activist and cultural communities I believe is beneficial for analytical purposes separating and classifying different political practices online. However from a transdisciplinary perspective it is important to keep in mind that these communities may blur into each other, intersect in networks and sometimes difficult to separate. As Ekelin (2007, pp. 68-69) underlines, exercising citizenship by electronic means, could be regarded as a continual activity, based on co-construction, blurring boundaries between parliamentary authorities, activist, private actors and inhabitants. Politics and power are properties of relationships between these actors (Ekelin, 2007, p. 74).

From an activist community perspective the Internet is a more egalitarian platform for communication that transcends territoriality and state censorship. This is widely discussed by Shirky in his book Here Comes Everybody (2009). From an activist point of view, the more free and less authoritarian infrastructure online networks provides, the more democratic potential they have, such as political actions opposing election results in countries such as Iran have bear witness on (Christensen, 2009). Jenkins (2006) is also theorizing Internet participation from a bottom-up perspective, but he is discussing participation in a more popular cultural community setting. What digital technology does for activist and popular cultural communities is to remove barriers to collective action: locality of information and barriers to group action (Shirky, 2009, p. 153). Digital technology enhances cooperation and coordination for group action towards ends that is sometimes hard to predict. Loosely structured groups are often coordinated without managerial supervision. However a shared digital platform may conclude with cooperation and even collective action. In order for this to happen shared beliefs and values (community) are important (Shirky, 2009, p. 163). Awareness, beliefs and values are communicated on digital platforms today. Especially from an activist community perspective, digital platforms enable like-minded people to act collectively without having to go through official organizations, territorial barriers and state censorship. Prominent examples are the protests and gatherings against election results in Moldova and Iran 2009. But there are also examples from Western democracies of this kind of activism. In Sweden, for example, online communities of bloggers managed to put issues of surveillance, integrity and privacy to debate in connection to the passing of a law giving the state rights to record its citizens (FRA). The politicians largely framed the issue in an anti-terrorist discourse, but through the bloggers and web-pages opposing the passing of this law, they managed to create an opinion and get the initial proposal turned down in the Parliament.

Parliamentary online communities often depart from a deliberative understanding of democracy consisting of debating and public spirited citizens, attentive to the interests of others, and willing to transform their preferences in process of deliberation (Dryzek, 2000). Within parliamentary online communities there are also more instrumental understandings of e-government as aiming at rationalizing and modernizing public administration and its relations with citizens, enabling to realize a better and more efficient administration (Ekelin, 2007, p. 1). Side by side with this instrumental discourse Ekelin (2007) discusses e-government as also considering citizens active contribution. In this almost contradictory discourse, e-participation is described as processes of governance through deliberative discussions with the dual purpose of both empowering citizens and helping to renew the representative democratic model of democracy and fight the perceived growing democratic deficit (Ekelin, 2007, p. 22). Within such deliberative discourses, e-participation is envisioned to benefit citizens, raise their interest for politics, open up for increased direct civic involvement, 
active citizen participation, and the overall modernisation of the governmental sector (Ekelin, 2007, p. 21). Internet practices within this framework are often envisioned as form of virtual agora of ideas and rational discussion.

Important to keep in mind that even though e-government slips between an instrumental discourse of administrative rationalisation and a deliberative discourse of e-participation (Ekelin, 2007, p. 23), it is almost always framed from a top-down perspective within parliamentary communities, in the service of representative democracy (as opposed to activist and popular cultural communities). Within parliamentary communities, e-government tends to reinforce the consultation aspect rather than empowerment and direct decision-making (see Ekelin, 2007, pp. 26-27). However, there are examples of top-down e-participatory initiatives that aim for bottom-up participation. Local issues discussion forums (see Smith, 2009) for example aspire to generate a permanent local issue-based deliberative debate that invigorates local democracy from the bottom-up.

\section{Conclusion}

Convergence, predicting a loss of control of old media institutions, together with bottom up perspectives on political participation and municipal deliberative experiments, all suggest more possibilities for ordinary citizens to express themselves and organize group action, in a sense implying that everything is in the hands of the connected user. However, we need to be aware of that processes of governance sometimes preserves existing power relations and we also need to be aware of the ways commercial interests increasingly are monetizing on the information we generate about ourselves in for example social media. Some claim (see Terranova, 2004; Andrejevic, 2007) that the blurring of the categories of consumer and producer is a way to exploit free labour. It is also important to keep in mind that non-benevolent authorities and commercial interests may also use digital platforms in order to gather information about their citizens and potential consumers (Andrejevic, 2007; Christensen, 2009). As Andrejevic (2009) points out, Google will provide me with a free e-mail address if I let them data-mine my messages. Facebook will help me keep in touch with friends if I let them use information I post to learn about me and eventually target market to me (ibid.). Thus, theorizing citizenship(s) in ICT societies it is important not to put the issue of power aside, since communication in networks also will be unequal, divisive and stratifying, with certain nodes in the networks of online communities being more important than others (Dobson, 2003, $p$. 19). Digital technology may very well be used from a top-down perspective, as was also the case in Iran with authorities gathered information about who was interacting with foreign servers and acting upon this information (Christensen, 2009). Not only the citizens have more information and networking possibilities available than ever before to act upon, monitoring capabilities of digital technology combined with increasing possibilities for data storage and sorting, marketers and nation states have access to unprecedented amounts of information about customers and citizens (Andrejevic, 2009).

On a positive note, I observe that in connected societies, the Internet is considered and used, as a new arena for political participation and action, both by established political communities, as well as by activist communities, resulting in lowering the threshold for participation and action, with new and different forms for engaging in politics, sometimes with the political even popping up in other non outspokenly political communities all over the socio-cultural landscape.

From the perspective of transdisciplinarity, our goal is to understand the present world (Nicolescu, 2001, p. 46). I claim that the concept of citizenship is vital in this quest to understand contemporary societies with its power relations and political struggles. Nicolescu $(2001$, p. 73 ) argues in his manifesto that individual and social evolution condition each other. The meaning and direction of this co-evolution I believe is impossible to address without attending to citizenship and its meanings. Understanding citizenship as participation in political communities, with communities as ensembles of people addressing the organization of society and making sense of this address in a similar way, emphasize meaning-making. Nicolescu (2001 p. 95) laments the dawn of human history when science and culture were inseparably united with questions of the meaning of life and human organization. Late modern reflexivity is about reclaiming meaning in a time with diminishing 
importance of traditions and religion. Instead we turn to ourselves as individuals constructed and given meaning through the networks and communities we adhere to. Citizenship and political communities is one facet of this meaning making practice in late modernity and should be studied as such.

\section{References}

Andrejevic, M. (2007). I spy: Surveillance and power in the interactive era. Lawrence, KS: University Press of Kansas. Andrejevic, M. (2009). Critical media studies 2.0: An interactive upgrade. Interactions. Studies in Communication and Culture, $1(1), 35-52$.

Arsenjuk, L. (2005). Introduktion till Jacques Rancière. Fronesis. Det politiska, 19-20, 86-95.

Barbalet, J. M. (1998). Citizenship: Rights, struggle and class inequality. Milton Keynes, UK: Open University Press. Bauman, Z. (2001). The individualized society. Cambridge, UK: Polity Press..

Beck, U. (1995). Att uppfinna det politiska: Bidrag till en teori om reflexiv modernisering. Göteborg, SE: Daidalos.

Beck, U. (1998). Risksamhället: På väg in i en annan modernitet. Göteborg, SE: Daidalos.

Bellamy, R. (2008). Citizenship: A very short introduction. New York, NY: Oxford University Press.

Benkler, Y. (2006). The wealth of networks: How social production transforms markets and freedom. New Haven, CT: Yale University Press.

Bennett, L. W., \& Entman R. M. (2001). The big spin: Communication and the transformation of pluralist democracy. In L. W. Bennett, \& R. M. Entman (Eds.), Mediated politics: Communication in the future of democracy (pp. 279-298). Cambridge, UK: Cambridge University Press.

Bentivegna, S. (2006). Rethinking politics in the world of ICT. In European Journal of Communication. 21(3), 295-309.

Boggs, C. (2000). The end of politics: Corporate power and the decline of the public sphere. New York, NY: Guilford Press.

Bosniak. L. (2006). The citizen and the alien: Dilemmas of contemporary membership. Princeton, NJ: Princeton University Press.

Bruns, A. (2009). Social media: Tools for user-generated content: Social drivers behind growing consumer participation in user-led content generation: Volume 2: User Engagement Strategies. Everleigh, UK: Smart Services CRC.

Camauêr, L. (2000). Feminism, citizenship and the media: An ethnographic study of identity processes within four women's associations. Stockholm, SE: Institutionen för Journalistik Medier och Kommunikation (JMK).

Carter, A., \& Stokes G. (1998). Liberal democracy and its critics. In A. Carter, \& G. Stokes (Eds.), Liberal democracy and its critics: Perspectives in contemporary political thought (Introduction). Cambridge, UK: Polity Press.

Castells. M. (2001). The internet galaxy: Reflections on the Internet, business and society. Oxford, UK: Oxford University Press.

Castles, S., \& Davidson, A. (2000). Citizenship and migration: Globalization and the politics of belonging. London, UK: MacMillian Press.

Christensen, C. (2009, July 28). Iran: Networked dissent. Le Monde Diplomatique.

Coleman, S., \& Blumler, J.G. (2009). The Internet and democratic citizenship: Theory, practice and policy. Cambridge, UK: Cambridge University Press

Cruikshank, B. (1999). The will to empower: Democratic citizens and other subjects. Ithaca, NY: Cornwell University Press

Dahlgren, P. (2001). The public sphere and the net: Structure, space and communication. In L. W. Bennett, \& R. M. Entman R. M. (Eds.), Mediated politics: Communication in the future of democracy (pp. 33-55). Cambridge, UK: Cambridge University Press.

Dahlgren, P. (2006). Civic identity and net activism: The frame of radical democracy. In L. Dahlberg, \& E. Siapera (Eds.), Radical democracy and the Internet: Interrogating theory and practice (pp. 55-72). London, UK: Palgrave MacMillan.

Delanty, G. (2002). Communitarianism and citizenship. In E. F. Isin, \& B. S. Turner (Eds.), Handbook of citizenship studies (pp. 159-174). London, UK: Sage.

Dobson, A. (2003). Citizenship and the environment. New York, NY: Oxford University Press.

Dryzek, J. (2000). Deliberative democracy and beyond: Liberals, critics, contestations. Oxford, UK: Oxford University Press.

Ekelin, A. (2007). The work to make eParticipation work. Blekinge Institute of Technology Doctoral Dissertation Series No 2007: 11. Karlskrona: Blekinge Institute of Technology.

Fagerfjord, A., \& Storsul, T. (2007). Questioning convergence. In T. Storsul, \& D. Stuedahl (Eds.), Ambivalence towards convergence: Digitalization and media change. Göteborg, SE: Nordicom.

Fishkin, J.S. (1991). Democracy and deliberation: New directions for democratic reform. New Haven, CT: Yale University Press. 
Frau-Meigs, D. (2007). Convergence, Internet governance and cultural diversity. In T. Storsul, \& D. Stuedahl (Eds.), Ambivalence towards convergence: Digitalization and media change. Göteborg, SE: Nordicom.

Fukuyama, F. (1992). The end of history and the last man. New York, NY: Maxwell Macmillan International.

Giddens, A. (1991). Modernity and self-identity: Self and society in the late modern age. Cambridge, UK: Polity Press.

Hoffman, J. (2004). Citizenship beyond the state. London, UK: Sage.

Horkheimer, M. (1947). Eclipse of reason. New York, NY: Oxford University Press.

Isin, E. F., \& Wood, P. (1999). Citizenship and identity. London: Sage.

Isin, E. F., \& Turner, B. S. (Eds.). (2002). Handbook of citizenship studies. London: Sage.

Jenkins, H. (2006). Convergence culture: Where old and new media collide. New York, NY: New York University Press.

Kivisto, P., \& Faist, T. (2007). Citizenship: Discourse, theory and transnational prospects. Malden, MA: Blackwell Publishing.

Linklater, A. (2002). Cosmopolitan citizenship. In E. F. Isin, \& B. S. Turner (Eds.), Handbook of citizenship studies (pp. 317332). London, UK: Sage.

Lister, R. (2002). Sexual citizenship. In E. F. Isin, \& B. S. Turner (Eds.), Handbook of citizenship studies (pp. 191-208). London, UK: Sage.

Lüders, M. (2007). Convergent forms of communication? In T. Storsul, \& D. Stuedahl (Eds.), Ambivalence towards convergence: Digitalization and media change. Göteborg, SE: Nordicom.

McNair, B. (2000). Journalism and democracy: An evaluation of the political public sphere. London, UK: Routledge.

Nicolescu, B. (2002). The manifesto of transdisciplinarity. Albany, NY: State University of New York Press

Nord, L. (2008). Medier utan politik. En studie av de svenska riksdagspartiernas syn på press, radio och TV. Stockholm, SE: Santérus Förlag.

Olsson, A. R. (2006). När medborgarna tystnar. In B. Djörke, L. Ilshammer, P. Karlberg, K. Klein, L. Niklasson, T. Ohlin, A. R. Olsson, K.-E. Tallmo, G. Watt, \& I. Åhman-Eklund (Eds.), Med- eller Motborgare? Nåt jävla inflytande ska man väl ha i en demokrati (pp. 67-79). Sundsvall, SE: Offentliga Rummet.

Peterson, O., Westholm, A., \& Blomberg, G. (1989). Medborgarnas Makt. Stockholm, SE: Carlsson Bokförlag

Pocock, J. G. A. (1995). The ideal of citizenship since classical times. In R. Beiner (Ed.), Theorizing citizenship (pp. 29-52). Albany, NY: State University of New York Press.

Roberts, B. (2009). Beyond the 'networked public sphere': Politics, participation and technics in web 2.0. FibreCulture, 14. Retrived from http://journal.fibreculture.org/issue14/issue14_roberts.html.

Schuck, P. H. (2002). Liberal citizenship. In E. F. Isin, \& B. S. Turner (Eds.), Handbook of citizenship studies (pp. 130-144). London, UK: Sage.

Shirky, C. (2009). Here comes everybody: How change happens when people come together. London, UK: Penguin.

Smith, R. M. (2002). Modern citizenship. In E. F. Isin, \& B. S. Turner (Eds.), Handbook of citizenship studies (pp. 105-116). London, UK: Sage.

Smith, S. (2009). Mediated citizenship in local issues discussion forums. Paper presented the Mediated Citizenship conference, University of Leeds, 17-18 September 2009.

Storsul, T., \& Stuedahl, D. (2007). Introduction: Ambivalence towards convergence. In T. Storsul, \& D. Stuedahl (Eds.), Ambivalence towards convergence: Digitalization and media change. Göteborg, SE: Nordicom.

Svensson, J. (2008). Kommunikation, medborgarskap och deltagardemokrati. En studie av medborgarutskotten i Helsingborg, Lund Studies in Media and Communication 10. Lund: Sociologiska institutionen.

Svensson, A. (2010). Young men, ICTs and sports: Fan cultures and civic cultures. In T. Olsson, \& P. Dahlgren (Eds.), Young people, ICTs and democracy: Theories, policies, identities, and websites. Göteborg, SE: Nordicom

Terranova, T. (2004). Network culture: Politics for the information age. London, UK: Pluto Press.

Thompson Klein, J., Grossenbacher-Mansuy, W., Häberli, R., Bill, A, Scholz, R. W., \& Welti, M. (Eds.). (2001). Transdisciplinarity: Joint Problem Solving among Science, Technology, and Society. Basel: Birkhauser Verlag.

Turner, B. S. (1994). Postmodern culture/ modern citizens. In B. van Steenberger (Ed.), The condition of citizenship (pp.153-168). London, UK: Sage.

\section{About the Author}

Jakob Svensson

Dr. Jakob Svensson (Karlstads universitet) has a PhD in Media and Communication Studies (12 June 2008). His particular interest is in Civic Communication and the construction of citizenship through communicative practices. Jakob is currently holding a position of an assistant professor in Media and Communication Studies at Karlstad University and is the director of the research network HumanIT (www.kau.se/en/humanit). 